\title{
ASPEK ETIK PEMILIHAN JENIS KELAMIN DALAM PROSES PRE-IMPLANTATION GENETIC DIAGNOSIS PADA REKAYASA REPRODUKSI IN VITRO FERTILITATION
}

\author{
Budi Santoso \\ drsantoso@yahoo.com
}

\begin{abstract}
ABSTRAK
Perkembangan ilmu pengetahuan dan teknologi begitu pesatnya, termasuk bidang kesehatan. Etika kedokteran juga sangat berhubungan dengan hukum. Hampir di semua negara ada hukum yang secara khusus mengatur bagaimana dokter harus bertindak dalam perawatan pasien dan penelitian. Bagi pasangan atau pribadi yang tidak bisa menjadi hamil secara alami ada berbagai teknik reproduksi dengan bantuan seperti inseminasi buatan dengan fertilisasi in vitro dan transfer embrio, yang mudah didapat di pelayanan kesehatan reproduksi. Melalui teknologi preimplantation genetic diagnosis (PGD) jenis kelamin janin dapat dipilih. Pemilihan jenis kelamin (sex-selection) merupakan salah satu bentuk pengaplikasian dari teknologi rekayasa genetika yang berkembang cukup pesat saat ini. Muncul pertanyaan apakah etis seseorang (orang-tua) menentukan jenis kelamin orang lain (anaknya) dengan sengaja?. Penelitian ini menggunakan metode penelitian kualitatif dengan pendekatan yuridis normatif. Hasil penelitian menemukan bahwa pemilihan jenis kelamin pada bayi tabung (in vitro fertilitation) melalui metoda Pre-implantation genetic diagnosis dengan menyingkirkan embryo yang lain tidak dibenarkan secara etika, kecuali atas indikasi medis.
\end{abstract}

Kata kunci : aspek etik, pemilihan jenis kelamin, bayi tabung.

\begin{abstract}
The development of science and technology is so rapid, including the health sector. Medical ethics is also very related to law. In almost all countries some laws specifically regulate how doctors must act in patient care and research. For couples or individuals who cannot get pregnant naturally, there are various assisted reproductive techniques such as artificial insemination with in vitro fertilization and embryo transfer, which are easily available in reproductive health services. Through genetic preimplantation diagnosis (PGD) technology, fetal sex can be chosen. Sex selection (sex-selection) is one form of application of genetic engineering technology that is developing quite rapidly now. Does the question arise whether a person's ethics (parents) deliberately determine the sex of another person (his child)? This study uses qualitative research methods with a normative juridical approach. The results found that the selection of sex in IVF (in vitro fertilization) through the method of Pre-implantation genetic diagnosis by removing other embryos is not ethically justified, except for medical indications.
\end{abstract}

Keyword : ethical aspects, sex selection, in vitro fertilitation.

A. PENDAHULUAN

Perkembangan

ilmu

pengetahuan dan teknologi begitu

pesatnya, dengan ilmu yang dimiliki oleh manusia, sudah banyak masalah yang berhasil dipecahkan. Rahasia alam semesta misalnya, telah banyak diungkapkan melalui kemajuan 
Budi Santoso, Aspek Etik Pemilihan Jenis Kelamin Dalam Proses Pre-Implantation Genetic Diagnosis...

ilmu tersebut, yang pada gilirannya menghasilkan teknologi-teknologi spektakuler, seperti bioteknologi, teknologi di bidang komputer, komunikasi maupun ruang angkasa ${ }^{1}$. Perkembangan teknologi tersebut menjangkau segala hal, termasuk bidang kesehatan. Sebagian besar ilmuwan percaya bahwa teknologi hadir dengan tujuan 'rehumanize', memanusiakan manusia dan menciptakan kualitas hidup terbaik bagi manusia dengan cara meminimalisir penderitaan dan meningkatkan harapan hidup baik melalui cara promotif, preventif, kuratif, maupun rehabilitatif ${ }^{2}$.

Etika telah menjadi bagian yang integral dalam pengobatan setidaknya sejak masa Hippocrates, seorang ahli pengobatan Yunani yang dianggap sebagai pelopor etika kedokteran pada abad ke-5 SM. Dari Hippocrates muncul konsep pengobatan sebagai profesi, dimana ahli pengobatan membuat janji di depan masyarakat bahwa mereka akan menempatkan kepentingan pasien mereka di atas kepentingan mereka sendiri ${ }^{3}$. Etika kedokteran juga sangat

\footnotetext{
${ }^{1}$ Prasetyo T, Barkatullah A.H, Filsafat,Teori \& Ilmu Hukum, Rajagrafindo persada, Jakarta, 2012, hlm.1 ${ }^{2}$ Rani Tiyas Budiyanti, 'Aspek Etika Pre-implantation Genetic Diagnosis (PGD) pada Teknologi Bayi Tabung,'(2015), Cdk -230/Vol.42

${ }^{3}$ Williams, John R (john Reynold), Panduan Etika Medis/John R. Williams; Penerjemah: Tim Penerjemah
}

berhubungan dengan hukum. Hampir di semua negara ada hukum yang secara khusus mengatur bagaimana dokter harus bertindak dalam perawatan pasien dan penelitian. Badan yang mengatur dan memberikan ijin praktek medis di setiap negara bisa dan memang menghukum dokter yang melanggar etika. Namun etika dan hukum tidaklah sama. Sangat sering, bahkan etika membuat standar perilaku yang lebih tinggi dibanding hukum, dan kadang etika memungkinkan dokter perlu untuk melanggar hokum yang menyuruh melakukan tindakan yang tidak etis. Hukum juga berbeda untuk tiap-tiap negara sedangkan etika dapat diterapkan tanpa melihat batas negara ${ }^{4}$.

Kemajuan ilmu pengetahuan dan teknologi medis memunculkan masalah etis baru yang tidak dapat dijawab oleh etika kedokteran tradisional. Reproduksi buatan, genetika, informatika kesehatan serta teknologi perbaikan kehidupan dan teknologi untuk memperpanjang kehidupan, kesemuanya memerlukan keterlibatan dokter, sangat berpotensi menguntungkan pasien namun juga sangat berpotensi merugikan pasien tergantung bagaimana menerapkannya.

\footnotetext{
PSKI FK UMY, Editor: dr. Sagiran, M.Kes.,Cet.1,Yogyakarta: PSKI FK UMY, 2006 ${ }^{4}$ Id
} 
Budi Santoso, Aspek Etik Pemilihan Jenis Kelamin Dalam Proses Pre-Implantation Genetic Diagnosis...

Masalah etis yang muncul dalam etika kedokteran sebagian besar berhubungan dengan masalah di awal kehidupan. Bagi pasangan atau pribadi yang tidak bisa menjadi hamil secara alami ada berbagai teknik reproduksi dengan bantuan seperti inseminasi buatan dengan fertilisasi in vitro dan transfer embrio, yang mudah didapat di pelayanan kesehatan reproduksi. Tidak ada satupun teknik yang tidak problematik baik bagi individu maupun bagi kebijakan publik.

Fertilisasi in vitro atau pembuahan in vitro (bahasa Inggris: in vitro fertilisation, IVF), atau sering disebut bayi tabung, adalah suatu proses pembuahan sel telur oleh sel sperma di luar tubuh sang wanita: in vitro ("di dalam gelas kaca"). Proses ini melibatkan pemantauan dan stimulasi proses ovulasi seorang wanita, mengambil suatu ovum atau sel-sel telur dari ovarium (indung telur) wanita itu dan membiarkan sperma membuahi selsel tersebut di dalam sebuah medium cair di laboratorium. Sel telur yang telah dibuahi (zigot) dikultur selama 2-6 hari di dalam sebuah medium pertumbuhan dan kemudian dipindahkan ke rahim wanita yang sama ataupun wanita yang lain, dengan tujuan menciptakan keberhasilan kehamilan.

Teknik-teknik IVF dapat digunakan dalam berbagai jenis situasi, dan merupakan salah satu teknik dalam teknologi reproduksi dengan bantuan untuk penanganan infertilitas. Teknikteknik IVF juga digunakan dalam surogasi kehamilan, yang dalam kasus ini sel telur yang telah dibuahi ditanam di dalam rahim 'titipan' wanita lain sehingga anak yang dilahirkan secara genetik tidak terkait dengan wanita tersebut. Dalam beberapa situasi, sel-sel sperma atau sel-sel telur donasi dapat digunakan. Sejumlah negara melarang atau sebaliknya melakukan regulasi ketersediaan pengerjaan IVF sehingga menimbulkan wisata fertilitas. Pembatasan atas ketersediaan IVF misalnya karena biaya dan usia untuk menghasilkan suatu kehamilan yang sehat dalam jangka waktu normal. Karena biaya prosedur ini, IVF umumnya diupayakan hanya setelah pilihan lain yang lebih murah telah gagal.

Kelahiran seorang "bayi tabung" pertama yang berhasil, yaitu Louise Brown, terjadi pada tahun 1978. Louise Brown dilahirkan sebagai hasil dari siklus alami IVF tanpa stimulasi. Robert 
Budi Santoso, Aspek Etik Pemilihan Jenis Kelamin Dalam Proses Pre-Implantation Genetic Diagnosis...

G. Edwards mendapat penghargaan Nobel Fisiologi atau Kedokteran pada tahun 2010, fisiolog yang terlibat dalam pengembangan proses ini bersama dengan Patrick Steptoe; Steptoe tidak memenuhi syarat untuk dipertimbangkan karena Penghargaan Nobel tidak diberikan secara anumerta. Dengan donasi sel telur dan IVF, wanita yang melewati masa reproduktifnya atau telah mengalami menopause masih dapat hamil. Adriana Iliescu sempat memegang rekor sebagai wanita tertua yang melahirkan dengan menggunakan IVF dan sel telur dari donasi, ketika ia melahirkan pada tahun 2004 di usianya yang ke-66 tahun, sebelum rekornya terlampaui pada tahun 2006. Setelah menggunakan IVF, dikatakan bahwa banyak pasangan dapat hamil tanpa perawatan kesuburan. Pada tahun 2012, diperkirakan bahwa lima juta anak telah lahir di seluruh dunia menggunakan IVF dan teknik

reproduksi berbantu lainnya ${ }^{5}$.

Sejalan dengan perkembangan teknologi reproduksi, masyarakat saat ini mulai berorientasi untuk mendapatkan anak yang sehat, salah satunya melalui diagnosis prenatal.

\footnotetext{
5 --1-----, Wikipedia, Fertilisasi in vitro, dalam www.id.wikipedia.org, diakses tanggal 11 November 2017
}

Identifikasi kecacatan janin sejak masih dalam kandungan melalui USG atau prosedur amniosintesis mulai dikembangkan. Hal tersebut dapat menjadi polemik seandainya ditemukan kecacatan pada anak yang dikandung, akankah dilanjutkan hidupnya atau sebaliknya digugurkan. Melalui teknologi preimplantation genetic diagnosis (PGD), tak hanya penyakit keturunan bisa dieliminasi, tapi jenis kelamin janin pun dapat dipilih. Teknologi diagnosa genetika tidak hanya menguntungkan untuk mendeteksi dan mengatasi penyakit yang diwariskan secara genetis. Teknologi canggih ini sekaligus mewujudkan impian memperoleh buah hati dengan jenis kelamin tertentu. Pemilihan jenis kelamin (sex-selection) merupakan salah satu bentuk pengaplikasian dari teknologi rekayasa genetika yang berkembang cukup pesat saat ini.

Sex- selection pada fungsi awalnya adalah sebuah teknologi yang berguna untuk membantu lahirnya bayi tanpa cacat bawaan yang terpaut pada kromosom Y, dimana kromosom Y akan diganti dengan kromosom $\mathrm{X}$ sehingga menghasilkan bayi perempuan yang tidak memiliki potensi cacat 
Budi Santoso, Aspek Etik Pemilihan Jenis Kelamin Dalam Proses Pre-Implantation Genetic Diagnosis...

bawaan. Rekayasa genetika (sexselection termasuk di dalamnya) muncul dengan didasari keinginan untuk menciptakan kesejahteraan manusia sendiri, namun pada perkembangannya muncul problem etis ketika azas kepentingan mulai menginvasi teknologi rekayasa genetika.

Sex-selection kemudian dimanfaatkan untuk pemilihan atas jenis kelamin tertentu. Implikasinya adalah, muncul berbagai macam problematika etis, ketika manusia memiliki kemampuan untuk merekayasa dan menentukan jenis kelamin calon manusia yang akan menjadi anaknya. Di sini akan muncul pertanyaan apakah etis seseorang (orang-tua) menentukan jenis kelamin orang lain (anaknya) dengan sengaja?

Untuk tujuan menyeleksi jenis kelamin tersebut, maka dilakukan pemilihan embrio yang membawa gen jenis kelamin yang diharapkan, laki-laki atau perempuan. Embrio yang membawa gen jenis kelamin yang tak sesuai dengan keinginan orang tua tak dipilih, tidak diimplantasi ke dalam rahim, dan di musnahkan. Berdasarkan latar belakang tersebut, maka penulis tertarik untuk menelaah masalah ini dengan judul : Aspek Etik Pemilihan Jenis Kelamin dalam Proses PreImplantation Genetic Diagnosis pada Rekayasa Teknologi Reproduksi In Vitro Fertilitation.

\section{Identifikasi Masalah}

Berdasarkan latar belakang masalah tersebut di atas maka di identifikasi satu masalah yang akan dibahas pada penelitian ini : Bagaimanakah etika pada pemilihan jenis kelamin pada bayi tabung ( in vitro fertilitation, melalui metoda Preimplantation genetic diagnosis dengan menyingkirkan embryo yang lain ?

\section{B. PEMBAHASAN}

\section{Teknologi Reproduksi Buatan}

Manusia sebagai makhluk hidup memiliki naluri untuk menjaga kelangsungan hidupnya di dunia. Salah satu sifat insaniah manusia adalah melanjutkan keturunannya sebagai pewaris peradabannya. Perkembangan ilmu pengetahuan dan teknologi ikut berpengaruh terhadap cara manusia mengembangkan keturunannya, sehingga saat ini terdapat dua cara manusia melangsungkan dan memperoleh keturunannya, yaitu secara alamiah yang dilakukan melalui hubungan langsung antara lawan jenis 
Budi Santoso, Aspek Etik Pemilihan Jenis Kelamin Dalam Proses Pre-Implantation Genetic Diagnosis...

dan melalui pemanfaatan teknologi yang dikenal juga dengan teknologi reproduksi berbantu (TRB) atau Assisted Reproductive Technology(ART).

$$
\text { Pada dasarnya proses }
$$

pembuahan yang alami terjadi dalam rahim manusia melalui cara yang alami pula (hubungan seksual). Akan tetapi pada kondisi tertentu pembuahan alami ini terkadang sulit terwujud. Kondisi ini menyebabkan infertilitas yang menyebabkan manusia tidak dapat memiliki keturunan.

Kehadiran seorang anak merupakan dambaan setiap pasangan suami istri, akan tetapi tidak semua pasutri dapat dengan mudah memperoleh keturunan. Kurang lebih 11-15\% pasangan suami istri mengalami kesulitan untuk memperoleh keturunan, baik karena kurang subur (subfertil) atau tidak subur (infertile). Bahkan pernah dilaporkan sekitar $25 \%$ pasangan tidak memperoleh keturunan setelah 12 bulan menikah. Di Indonesia sendiri tercatat 10-20\% pasangan adalah infertile, yang membutuhkan pertolongan untuk mengatasi ketidaksuburannya ${ }^{6}$.

\footnotetext{
6 TZ.Jacoeb, Bayi Tabung (fertilisasi in vitro) Sebagai Pilihan Pasangan Suami Istri Pendamba Anak, Yayasan SamMarie
}

Pada dua dekade terakhir ini, ilmu dan teknologi di bidang kedokteran mengalami perkembangan yang sangat pesat serta memberikan dampak positive bagi umat manusia. Salah satu hasil penemuan di bidang ini adalah dengan telah ditemukannya cara cara baru dalam mereproduksi manusia, yang dalam istilah kedokteran disebut in vitro fertilization atau lebih popular dengan istilah bayi tabung ${ }^{7}$. Sebelumnya kita terangkan terlebih dahulu mengenai proses konsepsi yang normal. Sebelum terjadi konsepsi, telur akan lepas dari salah satu indung telur (ovarium), dan berjalan menuju tuba fallopii. Bila sel telur tersebut bertemu sperma di tempat ini dan sperma berhasil menembus dinding sel telur, maka terjadilah pembuahan yang normal. Saat itulah gen dan kromosom dari sel telur dan sel sperma bersama sama membangun sebuah sel. Sel ini akan membelah diri menjadi kumpulan sel yang disebut blastosis. Blastosis bergerak di saluran telur turun ke dalam uterus, blastosis akan tertanam di dinding Rahim ${ }^{8}$.

\footnotetext{
Binafiat, Jakarta, 2002,hlm.1

${ }^{7}$ Koes Irianto, Biologi Reproduksi, Alfabeta, Bandung, 2014, hlm.314

${ }^{8}$ Ivan R Sini, Bayi Tabung ; Mempersiapkan Kehamilan, PT Gramedia, Jakarta, 2013, hlm.23-24
} 
Budi Santoso, Aspek Etik Pemilihan Jenis Kelamin Dalam Proses Pre-Implantation Genetic Diagnosis...

Pada hakikatnya program bayi tabung bertujuan untuk membantu pasangan suami-istri yang tidak mampu melahirkan keturunan secara alami yang disebabkan karena ada kelainan pada tubanya, endometriosis, oligospermia, unexplained infertility, dan adanya factor imunologi. Telah banyak pasangan yang telah terbantu dengan teknologi ini, walaupun di balik kebahagiaan itu ternyata program bayi tabung menimbulkan masalah dalam bidang agama dan hukum ${ }^{9}$.

Teknik TRB ( $\begin{array}{r}\text { Teknologi } \\ \text { Reproduksi Berbantu) merupakan }\end{array}$
serangkaian prosedur yang dapat
digunkan untuk membantu proses
pembuahan. Teknik yang paling
popular dan dilakukan di banyak
tempat adalah in vitro fertilization
dimana pada awalnya dilakukan
pematangan sel telur pada indung telur
wanita dengan berbagai obat obatan,
setelah terjadi pematangan, dilakukan
pengambilan dengan alat tertentu.
Kemudian di luar tubuh, dilakukan
pembuahan dengan sperma yang sudah
disiapkan, setelah menjadi embryo
dimasukan ke dalam rahim ibunya ${ }^{10}$.

2. Sex Selection

\footnotetext{
${ }^{9}$ Koes Irianto, loc.cit

${ }^{10}$ TZ.Jacoeb, op.cit, hlm.2-3
}

Teknologi reproduksi buatan adalah sebuah teknologi yang memungkinkan manusia untuk melakukan proses mendapatkan keturunan tanpa adanya coitus, tetapi dengan menyatukan sel-sel yang akhirnya bisa menghasilkan zigot. Dan salah satu bentuk pengaplikasian dari teknologi ini adalah sex- selection. Sex-selection pada fungsi awalnya adalah sebuah teknologi yang berguna untuk membantu lahirnya bayi tanpa cacat bawaan yang terpaut pada kromosom Y, di mana kromosom $\mathrm{Y}$ akan diganti dengan kromosom $\mathrm{X}$ sehingga menghasilkan bayi perempuan yang tidak memiliki potensi cacat bawaan. Rekayasa genetika (sexselection termasuk di dalamnya) muncul dengan didasari keinginan untuk menciptakan kesejahteraan manusia sendiri.

Sejalan dengan perkembangan teknologi reproduksi, masyarakat saat ini mulai berorientasi untuk mendapatkan anak yang sehat, salah satunya melalui diagnosis prenatal. Identifikasi kecacatan janin sejak masih dalam kandungan melalui USG atau prosedur amniosintesis mulai dikembangkan. Hal tersebut dapat menjadi polemik seandainya ditemukan 
Budi Santoso, Aspek Etik Pemilihan Jenis Kelamin Dalam Proses Pre-Implantation Genetic Diagnosis...

kecacatan pada anak yang dikandung, akankah dilanjutkan hidupnya atau sebaliknya digugurkan. Preimplantation genetic diagnosis (PGD) atau Pre-implantation genetic screening (PGS) muncul untuk mengatasi polemik tersebut. PGD dikembangkan untuk mengetahui profil genetik embrio agar dapat dilakukan seleksi sebelum implantasi sehingga dianggap lebih manusiawi. Teknik ini sering ditujukan untuk menghindari anak cacat lahir dari orang tua berisiko pada program bayi tabung atau in vitro fertilization (IVF) ${ }^{11}$.

PGD (Pre-implantation Genetic Diagnosis) merupakan teknik screening genetik embrio yang akan ditanam pada teknologi reproduksi bayi tabung (in vitro fertilization; IVF). Sperma dan telur di campurkan in vitro (di luar tubuh ibu). Pada PGD, teknik IVF adalah intracytoplasmic sperm injection (ICSI), yaitu single sperma diambil dan disuntikan ke dalam sel telur hingga menjadi embryo. Embrio yang diperoleh akan dikembangkan dalam laboratorium selama tiga hari menjadi delapan sel. Pada tahap ini, embrio berpotensi

11 Rani Tiyas Budiyanti, Aspek Etika Pre-implantation Genetic Diagnosis (PGD) pada Teknologi Bayi Tabung Dalam Cermin Dunia Kedokteran, 230/Vol.42n0.7 Thn 2015 berkembang menjadi beberapa jaringan tubuh yang dikenal dengan totipoten. Satu atau dua sel tersebut kemudian diambil untuk sampel in vitro yang disebut dengan embryo biopsy. Sel embrio biopsi tersebut dapat diperiksa dengan dua metode, yaitu metode polymer chain reaction (PCR) dan fluorosence in situ hybridization (FISH). Jika abnormalitas genetik berkaitan dengan single DNA, maka dilakukan skrining PCR. Sedangkan, jika abnormalitas berhubungan dengan abnormalitas kromosom atau untuk menentukan jenis.kelamin (kromosom Y) embryo, maka digunakan FISH. Pada tahun 1990, PGD pertama kali digunakan untuk genetic screening pada mutasi cystic brosis. Seiring dengan perkembangannya, PGD mulai dilakukan pada penyakit genetik dan ireversibel seperti sickle-cell anemia, Tay- Sachs, Duchenne's muscular dystrophy, dan beta-thallasemia. Beberapa tujuan PGD antara lain:

\section{a. Monogenic Disorder}

Saat ini, PGD banyak digunakan untuk gangguan monogenik, yaitu gangguan kromosom karena gen tunggal (autosomal resesif, autosomal dominan atau X-linked). PGD akan mengidentifikasi embrio pembawa 
Budi Santoso, Aspek Etik Pemilihan Jenis Kelamin Dalam Proses Pre-Implantation Genetic Diagnosis...

penyakit genetik atau kelainan kromosom, agar dapat menghindari kelahiran anak yang sakit. Penyakit gangguan autosomal resesif yang paling sering didiagnosis adalah cystic brosis, thalassemia beta, penyakit sel sabit, dan atropi otot tulang belakang tipe 1 . Penyakit autosomal dominan yang paling umum adalah miotonia distropi, penyakit Huntington, dan penyakit Charcot-Marie-Tooth, sedangkan kasus yang berhubungan dengan kromosom $\mathrm{X}$ adalah hemofilia A dan muscular distrophy Duchenne. PGD juga sekarang sedang dilakukan untuk penyakit multiple exostoses herediter (MHE/MO/HME). Selain itu, ada pasangan pembawa gen resesif penyakit yang memilih PGD karena dapat dengan mudah dikombinasikan dengan perawatan $\mathrm{IVF}^{12}$

\section{b. Penentuan Peluang Kehamilan}

PGD telah disarankan sebagai metode untuk menentukan kualitas embrio yang difertilisasi in vitro, untuk memilih embrio yang tampaknya memiliki peluang terbesar untuk kehamilan sukses. Namun, karena bergantung dari penilaian sel tunggal, PGD memiliki keterbatasan karena bersifat acak yang mungkin tidak mewakili embrio.

\section{c. Penyelamat Saudara (savior siblings)}

Savior siblings merupakan anak yang sengaja dilahirkan untuk menyediakan donor organ atau jaringan yang akan ditransplantasikan kepada saudara terdahulunya yang menderita penyakit seperti thalassemia- $\beta$ atau anemia Fanconi. Dalam transplantasi, kecocokan human leucocyte antigen (HLA) antara donor dan resipien merupakan hal yang penting. HLA sudah dapat diketahui sejak masih dalam bentuk embrio. PGD dapat menyeleksi embrio yang memiliki HLA yang sama dengan resipien dan bebas dari penyakit genetik dan selanjutnya akan ditanam dalam rahim pada proses bayi tabung. Transplantasi terbaik yang dilakukan adalah dengan transplantasi stem cell hematopoetik yang didapat dari tali pusat janin resipien yang dilahirkan.

\section{d. Identifikasi dan Pemilihan}

\section{Jenis Kelamin}

PGD dapat mengetahui jenis kelamin embrio bahkan sebelum implantasi. Sebuah survei tahun 2006 menemukan bahwa 42 persen klinik yang menawarkan PGD telah 
Budi Santoso, Aspek Etik Pemilihan Jenis Kelamin Dalam Proses Pre-Implantation Genetic Diagnosis...

menyediakan seleksi jenis kelamin untuk alasan non-medis. Hampir setengahnya melakukan itu hanya untuk "menyeimbangkan jenis kelamin keluarga", yaitu jika pasangan dengan dua anak atau lebih dari satu jenis kelamin menginginkan anak dengan jenis kelamin yang lain ${ }^{13}$.

\section{e. Etika dalam Teknologi}

\section{Reproduksi Berbantu}

Etika berasal dari bahasa Yunani "ethos" dalam bentuk tunggal, atau "etha" dalam bentuk jamak. Etika dalam bahasa latin sama dengan moral, yang berasal dari akar kata "mos" atau "mores", yang diartikan kebiasaan, adat, norma, etik yang berlaku. Lebih lanjut Poerwadarminta (1953) dalam Kamus Lengkap Bahasa Indonesia menyimpulkan bahwa etika adalah sama dengan akhlak, yaitu pemahaman tentang apa yang baik dan apa yang buruk, serta pemahaman tentang hak dan kewajiban orang. Etika sebagai kajian ilmu membahas tentang moralitas atau tentang manusia terkait dengan perilakunya terhadap manusia lain dan sesama manusia ${ }^{14}$.

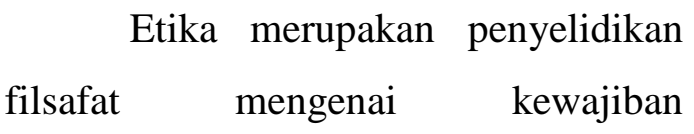

\footnotetext{
${ }^{13} \mathrm{Id}$

${ }^{14}$ Soekidjo N, Etika dan Hukum Kesehatan, Rineka Cipta, Bandung, 2010, hlm 1
}

kewajiban manusia serta tingkah laku manusia dilihat dari segi baik dan buruknya tingkah laku tersebut. Etika dibutuhkan sebagai pengantar pemikiran kritis yang dapat membedakan antara apa yang sah dan apa yang tidak sah; membedakan apa yang benar dan apa yang tidak benar. Dengan demikian etika memberi kemungkian kepada kita untuk mengambil sikap sendiri serta ikut menentukan arah perkembangan masyarakat ${ }^{15}$.

Pandangan lain menyimpulkan pula bahwa etika merupakan kajian mengenai moralitas, refleksi terhadap moral secara sistematis dan hati hati, dan analisis terhadap keputusan moral dan perilaku baik pada masa lampau, sekarang atau masa mendatang. Moralitas merupakan dimensi nilai dari keputusan dan tindakan yang dilakukan manusia, sehingga dapat disimpulkan bahwa perilaku beretika dapat diartikan sebagai perilaku yang mendatangkan kebaikan, kebenaran, kebahagiaan, dan perilaku yang bertanggung jawab ${ }^{16}$.

\footnotetext{
${ }^{15}$ Juhaya S.P, Aliran-Aliran Filsafat \& Etika, Kharisma Putra Utama, Jakarta, cet 5, 2014, hlm.59-60

${ }^{16}$ Sri Siswati, Etika dan Hukum Kesehatan; Dalam Perspektif Undang-Undang Kesehatan, Rajagrafindo Persada, Jakarta, cet.2,2015, hlm.177-178
} 
Budi Santoso, Aspek Etik Pemilihan Jenis Kelamin Dalam Proses Pre-Implantation Genetic Diagnosis...

Etika pada umumnya bersifat universal ditentukan oleh kelompok atau masyarakat tertentu. Meskipun bersifat universal yang bersumber pada hati nurani manusia, tetapi masing masing kelompok masyarakat atau bangsa mempunyai rumusan yang berbeda $^{17}$. Etika bagi kelompok profesi termasuk dalam etika khusus, yang sudah mempunyai aturan-aturan etik yang jelas, dan tertulis dalam suatu kode etik profesi. Oleh sebab itu, bagi kelompok profesi yang sudah mempunyai kode etik, sanksi pelanggaran etik adalah hukuman profesi, yang telah diatur dalam kode etik profesi tersebut ${ }^{18}$.

Tujuan dikembangkannya etika profesi ini adalah untuk mengatur hubungan timbal balik antara kedua belah pihak, yakni antara anggota kelompok atau anggota masyarakat yang melayani dan yang dilayani. Dalam bidang kesehatan, dengan sendirinya etika profesi ini berkembang dari hubungan antara para petugas kesehatan dan masyarakat yang dilayani $^{19}$. Etika profesi kedokteran merupakan seperangkat perilaku para dokter dalam hubungannya dengan

\footnotetext{
${ }^{17}$ Soekidjo N, op.cit. hlm.11

${ }^{18}$ Ibid hlm.14

${ }^{19}$ Ibid hlm.34
}

pasien, keluarga, masyarakat, teman sejawat, dan mitra kerja. Prinsip umum etik kedokteran berdasarkan 4 prinsip etik biomedis (Beuchamp \& Childress, 2001) yaitu : respect for autonomy, beneficence, nonmaleficence, justice ${ }^{20}$.

Pada proses teknologi bayi tabung, sel sperma ayah dan sel telur ibu bertemu diluar tubuh ibu. Jadi dokter mengambil sperma dari ayah dan sel telur dari ibu. Kemudian dalam kondisi steril, sel sperma dan sel telur dipertemukan, dalam tabung atau cawan petri. Tentu saja tahapan tahapan bayi tabung mempunyai implikasi terhadap hukum, agama, dan etik, yang memerlukan pertimbangan berbagai disiplin ilmu terkait ${ }^{21}$.

Timbulnya persoalan di bidang agama adalah disebabkan karena di dalam berbagai agama tidak dikenal anak yang dihasilkan dari teknik bayi tabung, tetapi yang dikenal adalah anak yang dihasilkan dari hubungan badani antara pasang suami-istri. Sehingga para tokoh agama harus mencari dan menemukan di dalam kitab suci masing-masing hal-hal yang ada kesamaannya dengan hal tersebut. Sedangkan persoalan hukum timbul

\footnotetext{
${ }^{20}$ Jusuf H, Amri A, Etika Kedokteran \& Hukum Kesehatan, EGC, Jakarta, ed 5,2017, hlm. 3-4

${ }^{21}$ Ibid, hlm. 140-141
} 
Budi Santoso, Aspek Etik Pemilihan Jenis Kelamin Dalam Proses Pre-Implantation Genetic Diagnosis...

disebabkan karena peraturan perundang undangan yang mengatur kedudukan hukum anak yang dilahirkan melalui proses bayi tabung belum ada, sedangkan hukum itu bertujuan untuk melindungi kepentingan manusia agar di dalam masyarakat terdapat ketertiban, keadilan dan kepastian hukum ${ }^{22}$.

Mengakui hak seseorang untuk dapat melaksanakan fungsi reproduksinya berarti melakukan segala tindakan yang memungkinkan individu tersebut untuk mengatasi masalah ketidaksuburannya. Di balik keberhasilan program bayi tabung, terdapat pula banyak masalah moral dan etika. Banyak pihak ynag beranggapan bahwa penelitian bayi tabung bermain main dengan kehidupan manusia karena telah mencampuri proses sacral dari penciptaan manusia yang merupakan hak prerogative Tuhan yang pencipta ${ }^{23}$.

Di luar negeri, seperti Inggris, Amerika Serikat, Australia, dan Afrika Selatan tidak saja mengembangkan jenis bayi tabung yang berasal dari pasangan suami-istri yang sah kemudian ditanamkan ke istri yang sah, tetapi juga sudah mengembangkan jenis bayi tabung lain, seperti : sperma dari donor,

\footnotetext{
${ }^{22}$ Koes Irianto, loc.cit.

${ }^{23}$ TZ.Jacoeb, op.cit, hlm.81-82
}

ovumnya dari istri, kemudian embryonya ditanamkan di rahim istri, atau sperma dan ovum dari suami istri, kemudian embryonya ditanamkan ke dalam rahim surrogate mother ${ }^{24}$.

$$
\text { Penerapan bayi tabung di }
$$

Indonesia mengacu kepada pasal 127 Undang- undang No 36 Tahun 2009 tentang kesehatan yang berbunyi :

(1) Hasil pembuahan sperma dan ovum dari suami-istri yang bersangkutan ditanamkan dalam rahim istri dari mana ovum berasal.

(2) Dilakukan oleh tenaga kesehatan yang mempunyai keahlian dan kewenangan untuk itu.

(3) Pada fasilitas pelayanan kesehatan tertentu $^{25}$

Belum diperkenankannya jenis bayi tabung yang lain, seperti sperma donor, dan surrogate mother dikembangkan di Indonesia saat ini adalah disebabkan karena masyarakat Indonesia masih menjunjung tinggi nilai-nilai budaya dan agama ${ }^{26}$.

\section{f. Etika dalam Sex Selection}

Sejak ratusan tahun sebelum masehi, masyarakat memiliki budaya untuk memilih anak dengan jenis

\footnotetext{
${ }^{24}$ Koes Irianto, op.cit, hlm.317

${ }^{25}$ Joni Afriko, Hukum Kesehatan; (teori dan aplikasinya), InMedia, Bogor, 2016,hlm.105

${ }^{26}$ Koes Irianto, loc.cit
} 
Budi Santoso, Aspek Etik Pemilihan Jenis Kelamin Dalam Proses Pre-Implantation Genetic Diagnosis...

kelamin tertentu; memilih anak laki-laki lebih sering dari anak perempuan. Perkembangan ilmu genetika dan teknologi reproduksi memperluas pilihan seseorang untuk menentukan kualitas keturunan yang diinginkannya. Pilihan tersebut tidak hanya berupa penapisan terhadap kemungkinan terjadinya penyakit keturunan, tetapi juga untuk menyeleksi jenis kelamin anak (gender) yang diinginkan ${ }^{27}$.

Teknologi bayi tabung memberikan peluang kepada para pasangan untuk dapat mengetahui jenis kelamin dan kelainan genetik yang mungkin terjadi pada embrio, sehingga dapat menghindari kemungkinan implantasi embrio cacat. Sebelum sel embryo ditanamkan ke dalam rahim, dilakukan pengambilan sampel untuk diperiksa dengan dua metode, yaitu metode polymer chain reaction (PCR) dan fluorosence in situ hybridization (FISH). Jika abnormalitas genetik berkaitan dengan single DNA, maka dilakukan skrining PCR. Sedangkan, jika abnormalitas berhubungan dengan abnormalitas kromosom atau untuk menentukan jenis kelamin (kromosom Y) embrio, maka digunakan $\mathrm{FISH}^{28}$.

\footnotetext{
${ }^{27}$ Jusuf H, Amri A, op.cit, hlm. 141

${ }^{28}$ Rani Tiyas Budiyanti, op.cit,hlm.14-15
}

PGD dapat mengetahui jenis kelamin dan penyakit yang mungkin terkait (X-linked disorder), hingga sering terjadi permintaan untuk mengubah jenis kelamin agar embrio tersebut tidak terkena penyakit. Menurut FIGO, pemilihan jenis kelamin untuk menghindari penyakit yang diturunkan merupakan hal yang diperbolehkan. Yang menjadi masalah adalah jika permintaan oleh orang tua yang menginginkan anak dengan jenis kelamin tertentu sebagai family balancing. Pada tahun 2000 di Italia, Alan dan Louise Masterton mendaftar kepada HFEA (Human Fertilisation and Embryology Authority) untuk meminta ijin melakukan PGD agar mendapatkan bayi perempuan setelah kematian anak perempuannya akibat kecelakaan. Pasangan tersebut telah memiliki 4 anak laki-laki dan Mrs. Masterton telah melakukan sterilisasi setelah kehamilan kelima. HFEA mengijinkan, akan tetapi ternyata ketiga embrio yang digunakan gagal. Di Inggris, penggunaan PGD untuk family balancing dilarang oleh hukum. Di Cina dan India, pemilihan jenis kelamin ini merupakan hal yang berpotensi untuk di- perdagangkan mengingat di kedua negara tersebut para orang tua sering 
Budi Santoso, Aspek Etik Pemilihan Jenis Kelamin Dalam Proses Pre-Implantation Genetic Diagnosis...

kali lebih memilih anak dengan jenis kelamin laki- laki. Di Indonesia belum ada peraturan yang mengatur mengenai hal tersebut ${ }^{29}$.

Seleksi kelamin atas indikasi medis dengan tujuan menghindari terjadinya sex linked genetic disorder , misalnya penyakit hemophilia dapat dibenarkan. Namun untuk indikasi nonmedik masih terdapat perbedaan pendapat. Seleksi kelamin ini tentunya menimbulkan perdebatan dari segi hukum, etika, dan social. Untuk indikasi nonmedik ini, ada yang setuju dan ada yang tidak setuju dengan seleksi kelamin. Bagi yang tidak setuju menggangap tindakan tersebut sebagai diskriminasi kelamin dan bertentangan dengan keadilan, sebagai salah satu prinsip etika profesi kedokteran ${ }^{30}$.

Jika sex-selection diperbolehkan secara bebas, sex-selection hanya akan menjadi industrialisasi di dunia kedokteran, karena akan menjadi semakin marak, dan chaos yang lebih banyak akan muncul. Apalagi dalam dunia medis, tanpa bukti-bukti yang kuat tindakan medis tidak dapat dilakukan kecuali alasan yang penting

\footnotetext{
${ }^{29}$ Rani Tiyas Budiyanti, op.cit, hlm.24-25

${ }^{30}$ Jusuf H, Amri A, op.cit, hlm. 141
}

dan mengancam jiwa, seperti itulah sex-selection, sex-selection yang bukan dikarenakan penyakit turunan (bersifat hereditas) tidak bisa dilakukan secara bebas.

\section{KESIMPULAN}

Pemilihan jenis kelamin pada bayi tabung ( in vitro fertilitation ) melalui metoda Pre-implantation genetic diagnosis dengan menyingkirkan embryo yang lain tidak dibenarkan secara etika, kecuali atas indikasi medis.

\section{DAFTAR PUSTAKA}

Ivan R Sini, Bayi Tabung ; Mempersiapkan Kehamilan, PT Gramedia, Jakarta, 2013.

Joni Afriko, Hukum Kesehatan; (teori dan aplikasinya), InMedia, Bogor, 2016. Juhaya S.P, Aliran-Aliran Filsafat \& Etika, Kharisma Putra Utama, Jakarta, cet 5, 2014.

Jusuf H, Amri A, Etika Kedokteran \& Hukum Kesehatan, EGC, Jakarta, ed 5, 2017.

Koes Irianto, Biologi Reproduksi, Alfabeta, Bandung, 2014.

Moh.Hatta, Hukum Kesehatan \& Sengketa Medik, Lyberti, Jogjakarta, 2013 
Budi Santoso, Aspek Etik Pemilihan Jenis Kelamin Dalam Proses Pre-Implantation Genetic Diagnosis...

Prasetyo T, Barkatullah A.H,

Rajagrafindo Persada, Jakarta,

Filsafat,Teori \& Ilmu Hukum, cet.2,2015.

Rajagrafindo persada, Jakarta, 2012.

TZ.Jacoeb, Bayi Tabung (fertilisasi in vitro) Sebagai Pilihan Pasangan

Suami Istri Pendamba Anak, Yayasan SamMarie Binafiat, Jakarta, 2002

Rani Tiyas Budiyanti, 'Aspek Etika Preimplantation Genetic Diagnosis (PGD) pada Teknologi Bayi Tabung,'(2015), Cdk 230/Vol.42n0. Soekidjo N, Etika dan Hukum Kesehatan, Rineka Cipta, Bandung, 2010.

Williams, John R (john Reynold), Panduan Etika Medis/John R. Williams; Penerjemah: Tim Penerjemah PSKI FK UMY. Editor: dr. Sagiran, M.Kes.,Cet.1,Yogyakarta: PSKI FK UMY, 2006.

Wiryawan $\mathrm{P}$, Tono $\mathrm{Dj}$, Harris $\mathrm{H}$, Memahami Fertilisasi In Vitro, Refika Aditama, Bandung, 2010. vitro, dalam www.id.wikipedia.org, diakses tanggal 11 November 2017.

Sri Siswati, Etika dan Hukum Kesehatan; Dalam Perspektif Undang-Undang Kesehatan, Zaeni Asyhadie, Aspek-aspek Hukum Kesehatan di Indonesia, Rajawali Pers, Depok, 2017. 